\title{
SEMEN CHARACTERISTICS OF THE AMAZONIAN JUNDIÁ (Leiarius marmoratus GILL, 1870)
}

\section{CARACTERÍSTICA SEMINAL DE JUNDIÁ AMAZÔNICO (Leiarius marmoratus GILL, 1870)}

\author{
Rodrigo Diana NAVARRO' ${ }^{1}$;vo PIVATO ${ }^{2}$ \\ 1. Laboratório de Aquicultura e de Biotecnologia em Organismos Aquáticos, Faculdade de Agronomia e Medicina Veterinária, \\ Universidade de Brasília, Campus Universitário Darcy Ribeiro, Brasília, DF, Brasil. navarrounb@gmail.com; 2. Laboratório de \\ Reprodução Animal, Faculdade de Agronomia e Medicina Veterinária, Universidade de Brasília, Campus Universitário Darcy Ribeiro, \\ Brasília, DF, Brasil
}

\begin{abstract}
The study evaluated qualitative and quantitative characteristics of Amazonian jundiá semen. The experiment was carried out in February 2015 at Cia do Peixe, a company located in Goiás state, Brazil, that specialises in fish fry production. Three male L. marmoratus farmed in dugout ponds, weighing $1.34 \pm 0.29 \mathrm{~kg}$ and measuring $39.33 \pm$ $1.15 \mathrm{~cm}$ in length, were tested. The specimens were captured and transferred to a 1000-L tank at the Reproduction Laboratory of the abovementioned company. Water temperature was measured at 7:00 a.m. and 5:00 p.m., and the fish were fed twice daily. For semen collection, the fish were captured from the tank using a dip net and constrained with a wet cotton towel. Their eyes were covered and their urogenital papilla was cleaned and dried with paper towel. Semen was collected in microcentrifuge tubes that were immersed in ice and analysed immediately. On average, the sperm motility rate was $83.33 \%$, motility duration was $5.33 \mathrm{~min}$, sperm concentration was $1,795,833 \mathrm{cells} / \mathrm{mm}^{3}$, and vigour was 4 . The morphological analysis of the sperm revealed tail anomalies in $17.66 \%$, midpiece anomalies in $20 \%$, and head anomalies in $5.33 \%$. Based on qualitative and quantitative characteristics, L. marmoratus semen was shown to be suitable for use in artificial reproduction procedures.
\end{abstract}

KEYWORD: Motility rate. Motility duration. Espermatic morphological. South American catfish.

\section{INTRODUCTION}

Knowledge of the biology of a species, especially its reproductive aspects, is essential when you want to perform intensive fish farming (ANDRADE; YASUI, 2003).

The study of semen biology in native species is an important tool in aquaculture, as it allows reproduction in artificial conditions, having importance both in the commercial aspect for the development of technological packages for production in captivity and for management and conservation in restocking programs (CAROLSFELD et al., 2003; SILVA et al., 2009; VIVEIROS; GODINHO, 2009; SANCHES et al., 2011).

The Amazonian jundiá (leiarius marmoratus gill, 1870) is a catfish of the order Siluriformes and family Pimelodidae found in the Amazon, Orinoco, and Essequibo Rivers. Adapted to temperatures of 24 to $26^{\circ} \mathrm{C}$, it can reach $100 \mathrm{~cm}$ in length and weigh up to $12 \mathrm{~kg}$ (RAMIREZ-GIL; AJIACOMARTÍNEZ, 1997). The first studies on $L$. marmoratus reproduction were carried out by Christopher Kossowski in Venezuela. The Amazonian jundiá is a fish with potential for aquaculture due to its hardiness, its omnivorous preference, its ability to adapt well in intensive systems, and its white meat that is well accepted in the market. This species has an important role in aquaculture, Because the Amazonian jundai is widely used for hybridization in the northern, northeastern and mid-western regions of Brazil (CRUZCASALLAS et al. 2011; MIRA LOPES, 2010).

However, recent investigations report that high quality gametes of $L$. marmoratus are still difficult to obtain, likely due to management stress experienced in captivity and the decreasing availability of natural habitats (VIVEIRO et al., 2002, MIRA LOPES et al., 2010). Knowledge on the reproductive performance of this species and semen characteristic is scarce, proving the need for reflection on obtaining this information.

Assessment of the semen characteristics of Brazilian Amazonian fish is important in order to ascertain and improve their quality. The reproductive success of fish depends on improving artificial reproduction techniques, preserving male gametes, and studying the impacts of exposure to pollutants. This study evaluated the qualitative and quantitative characteristics of $L$. marmoratus semen. 


\section{MATERIAL AND METHODS}

The experiment was carried out in February 2015 at Cia do Peixe, a company located in Goiás state, Brazil, that specialises in fish fry production.

Three male L. marmoratus farmed in dugout ponds, weighing $1.34 \pm 0.29 \mathrm{~kg}$ and measuring $39.33 \pm 1.15 \mathrm{~cm}$ in length, were evaluated. The specimens were captured and transferred to a 1000$\mathrm{L}$ tank at the Reproduction Laboratory of the abovementioned company, where they were kept for 24 hours. Water temperature was measured at 7:00 a.m. and 5:00 p.m., and the fish were fed twice a day with a diet containing $42 \%$ crude protein. The mean temperature in the fish tank throughout the experiment was $26.0 \pm 0.50{ }^{\circ} \mathrm{C}$. The fish were induced by hormone $(1 \mathrm{mg} / \mathrm{kg})$.

\section{Semen collection}

For semen collection, the fish were captured from the tank using a dip net and constrained with a wet cotton towel. Their eyes were covered and their urogenital papilla was cleaned and dried with paper towel. Manual pressure was applied along the coelomic walls in the cranial-caudal direction to release semen without contamination by faeces, urine, blood, or water. Semen samples activated by early contact with water were discarded. Semen was collected in microcentrifuge tubes that were immersed in ice and analysed immediately.

For qualitative analysis, four drops of semen were deposited on a microscope slide and examined under an optical microscope at 400x magnification.

After confirming sample purity, indicated by motionless sperm, the sperm were activated with water from the tank to evaluate quality and suitability for cryopreservation. Sperm motility rate (\%) and motility duration (from activation until only
$10 \%$ of the cells continued moving) were determined.

\section{Sperm Concentration}

Using a Sahli haemoglobin pipette, semen was diluted in a 9.98 mLbuffer solution containing $4 \%$ formaldehyde and $96 \%$ saline (formaldehydesaline solution). The 1:500 solution produced was analysed using a Neubauer chamber. After filling the chamber by capillarity, sperm were counted in 5 squares on each side and the mean count was calculated. Sperm concentration was estimated according to the Brazilian College of Animal Reproduction standards (Colégio Brasileiro de Reprodução Animal) and the results were expressed as sperm per $\mathrm{mm}^{3}$ of semen.

\section{Morphological Analysis}

An aliquot of $10 \mu \mathrm{L}$ of fresh sample was diluted in $990 \mathrm{~mL}$ of formaldehyde-saline solution. A drop of diluted semen and a drop of rose Bengal stain were mixed and covered with a coverslip, removing the excess with a paper towel. The slides were observed using immersion oil under an optical microscope and in an Opton trinocular biological microscope (1600x magnification) at the Aquiculture Laboratory of the University of Brasília. Analysis was based on the examination of 100 sperm cells in several fields of the slide, as described by MILIORINI et al. (2011).

\section{RESULTS}

The average values of the semen assessed were: $83.33 \%$ motility, $5.33 \mathrm{~min}$ duration time, sperm concentration of $1,795,833$ cells/ $\mathrm{mm}^{3}$, and the vigour was 4 (Table 1, Figure 1).

Table 1. Characteristics of Amazonian jundia (Leiarius marmoratus) semen

\begin{tabular}{llllll}
\hline & Animal 1 & Animal 2 & Animal 3 & Mean & sd \\
\hline Motility rate (\%) & 90 & 80 & 80 & 83.33 & 5.77 \\
Motility duration (min) & 4 & 6 & 6 & 5.33 & 1.15 \\
Sperm concentration (cells $\left./ \mathrm{mm}^{3}\right)$ & $2,087,500$ & $1,587,500$ & $1,712,500$ & $1,795,833$ & $260,208.24$ \\
Vigour & 4 & 4 & 4 & 4 & 0
\end{tabular}

Sperm Morphology

Normal

54
58
56

56 


\begin{tabular}{|c|c|c|c|c|c|}
\hline Strongly coiled tail & 7 & 6 & 2 & 5 & 2.64 \\
\hline Strongly bent tail & 14 & 1 & 4 & 6.33 & 6.80 \\
\hline Tail degeneration & 2 & 6 & 3 & 3.66 & 2.08 \\
\hline Wrinkled tail & 1 & & 7 & 4 & 0 \\
\hline Total tail anomaly & 24 & 13 & 16 & 17.66 & 5.68 \\
\hline Total midpiece anomaly & 16 & 22 & 22 & 20 & 3.46 \\
\hline Detached head & 2 & 7 & 6 & 5 & 2.64 \\
\hline Microcephalia & 1 & & & 1 & 0 \\
\hline Total head anomaly & 3 & 7 & 6 & 5.33 & 2.08 \\
\hline
\end{tabular}

The totals of normal and anomaly sperm were $56 \%$ and $44 \%$, respectively, where tail abnormality was divided into strongly curled tail (5\%), strongly bent tail (6.33\%), shortened tail
(3.66\%), and wrinkled tail (4\%). The head abnormalities were loose head (5\%) and small head $(1 \%)$. There was abnormality rate of $20 \%$ in the intermediate piece (Table 1, Figure 1).
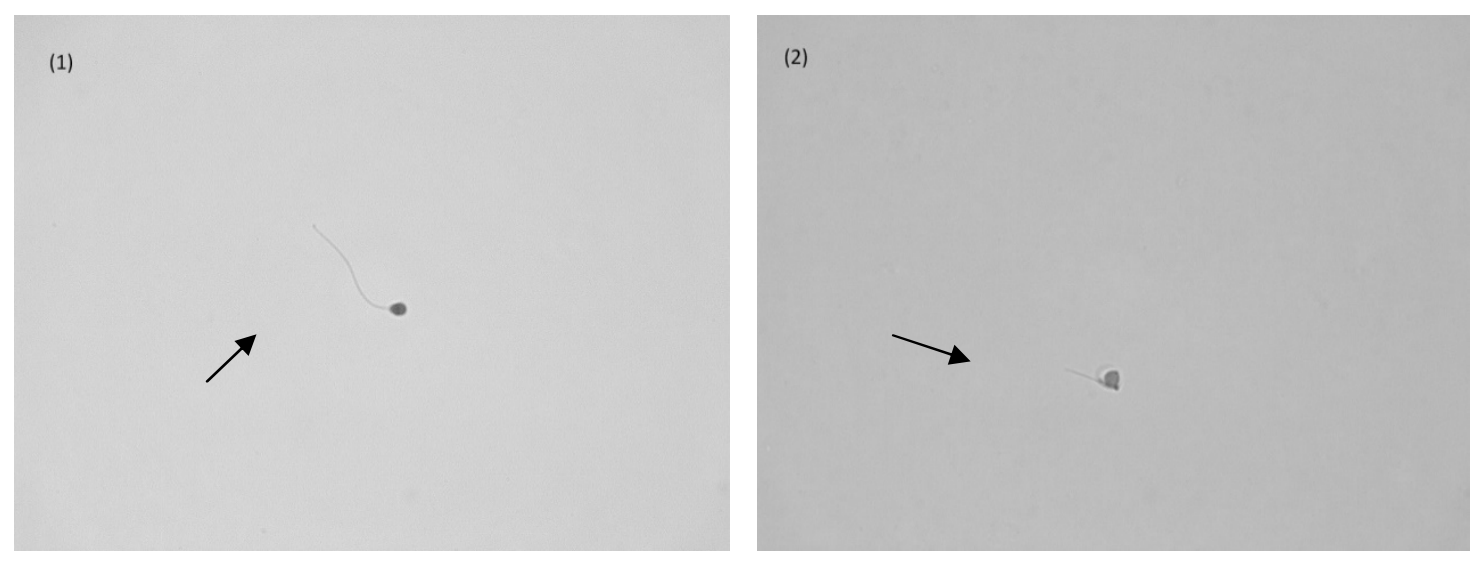

(3)

(4) 

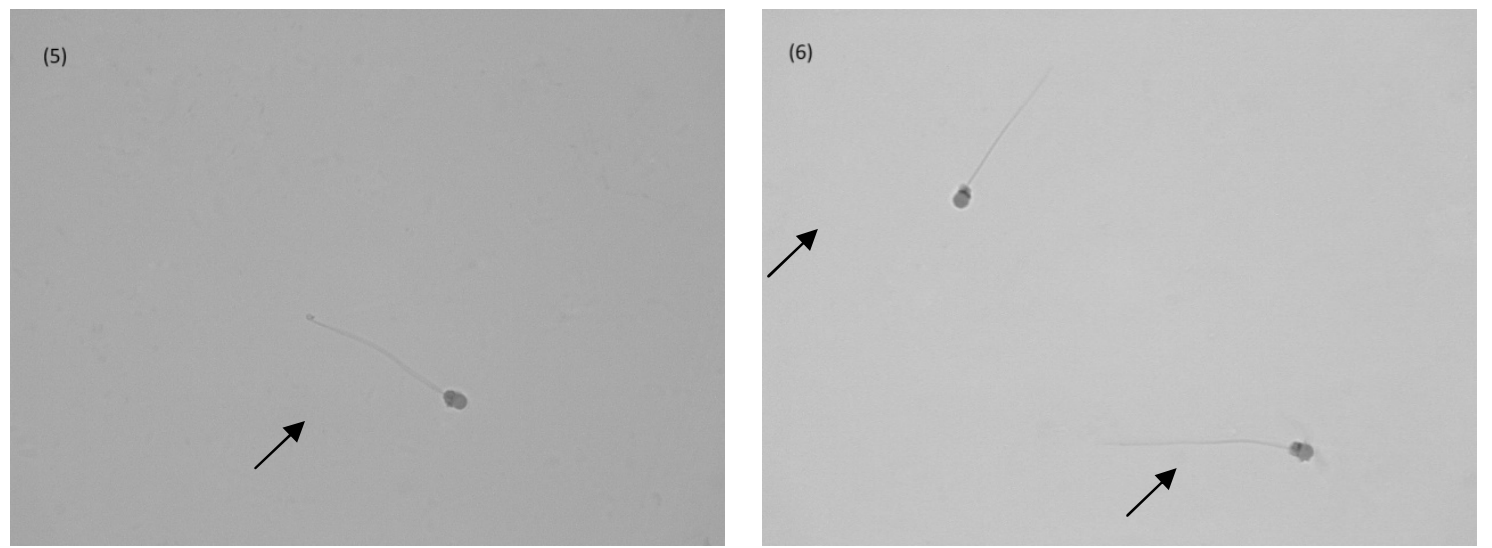

Figure 1. Normal sperm and sperm with primary and secondary anomalies (optical microscopy, 1600x magnification). (1) Normal sperm; (2) Sperm tail strongly coiled and bent around the head; (3) Tail degeneration; (4) Spermiogenesis failure with detachment of a normal head (indicated by the arrow); (5) Coiled tail tip and elongated head; (6) Head degeneration.

\section{DISCUSSION}

The mean motility of L. marmoratus semen was $83.33 \%$. Similar results were found in studies on another jundia species, Rhamdia quelen, which exhibited 72.5 to $80 \%$ motility in semen samples obtained without hormonal induction (FERREIRA et al., 2001; SOARES et al., 2010). The average motility duration was $5.3 \mathrm{~min}(318 \mathrm{~s})$ and vigour was 4. A wide variation in motility duration is reported for Brazilian fish that adopt a reproductive strategy similar to that of L. marmoratus, such as cascudo preto (Rhinelepis aspera) (42.21 s) and $R$. quelen $(23.9 \pm 2.7$ to $26.2 \pm 3.4 \mathrm{~s}$ ) (SANCHES et al., 2011). Motility duration is an important variable because it indicates the time gametes (sperm/oocytes) have spent in water (SANCHES et al., 2011).

Sperm concentration is another important attribute of semen quality. In the present study, the concentration ranged from $1.5 \times 10^{9}$ to $2.08 \times 10^{9}$ cells $/ \mathrm{mm}^{3}$ (Table 1), which is lower than the $21.0 \pm$ $0.37 \times 10^{9}$ cells $/ \mathrm{mm}^{3}$ found in $R$. aspera semen (SANCHES et al., 2011). According to VIVEIROS; GODINHO (2009), sperm concentration is highly variable among native Brazilian species, Pimelodidae species that swim upstream to reproduce, L. marmoratus and $\mathrm{R}$. quelen. In $R$. quelen, sperm concentration varies from 50.0 to $66.0 \times 10^{9}$ cells $/ \mathrm{mm}^{3}$, and individual semen production is nearly $125.0 \times 10^{9} \quad$ cells $/ \mathrm{mm}^{3}$ (BORGES et al., 2005). Sperm concentration in wild Rhamdia hilarii is between 59,222,106 and $67,843,412 \mathrm{cel} / \mathrm{mm}^{3}$ (KAVAMOTO; FOGLI DA SILVEIRA, 1986).

In the present study, $56 \%$ of jundia semen was normal. Other studies report 90\% (KAVAMOTO et al., 1999) and 97\% (MILIORINI et al., 2011) normal sperm in Prochilodus lineatus, $64 \%$ in Leporinus elongatus (STREIT Jr. et al. 2008b), 57\% in the dorado Salminus maxillosus (STREIT Jr. et al. 2008a), 53\% in the cachara Pseudoplatystoma reticulatum (STREIT Jr. et al. 2012) and $16 \%$ in the Nile tilapia Oreochromis niloticus (MATAVELI et al. 2007). The variation of normal semen percentage found among the species is influenced by several factors such as the nutritional status of the fish, size, age, and time of the year (VIVEIROS; GODINHO, 2009; SANCHES et al., 2011; NAVARRO et al., 2014).

Midpiece defects were the main anomaly observed in L. marmoratus, followed by tail defects. Sperm defects can affect fertility in natural reproduction, particularly in some mammal species (SOARES et. al., 2010). To prevent loss of fertility, the Brazilian College of Animal Reproduction (CBRA) recommends that sperm anomalies not exceed $30 \%$ for equines and cattle and $20 \%$ for wild boars and sheep. In fish, sperm tail anomalies are known to compromise fertilisation (MILIORINI et al., 2011). The $44 \%$ sperm anomaly rate exhibited by $L$. marmoratus may be related to stressful conditions in captivity and handling during semen collection. According to MURGAS et al. (2011), fish semen is compromised primarily by factors that affect breeders, such as diseases, consanguinity, food restriction, and stress. The data obtained here can guide future studies toward improving farming conditions of breeders, raising fish farming profits, and improving the quality of gametes of native Brazilian fish.

\section{CONCLUSION}

Semen of the Amazonian jundia (Leiarius marmoratus Gill, 1870) exhibits qualitative and 
quantitative characteristics that make it suitable for use in artificial reproduction. This information can guide new experiments, improve the cultivation conditions, increase commercial activity, as well as knowing the number of gametes viable for aquaculture.

\section{ACKNOWLEDGMENTS}

We thank Cia do Peixe company for providing the facilities and fish used in the study, and the research team of AcquaUnB from the University of Brasília and all the students who contributed to the completion of the work.

RESUMO: Objetivou-se avaliar qualitativamente e quantitativamente as características seminais do Jundiá Amazônico. O experimento foi realizado em fevereiro de 2015, a Cia do Peixe, uma empresa localizada no Estado de Goiás, Brasil, especializada em produção de alevino. Três masculino L. marmoratus cultivados em tanques de esconderijo subterrâneo, pesando $1,34 \pm 0,29 \mathrm{~kg}$ e medindo $39.33 \pm 1,15$ centímetros de comprimento, foram testados. Os espécimes foram capturados e transportado para um tanque de 1000 L no Laboratório da empresa acima indicado reprodução. A temperatura da água foi medida a 07:00 e 17:00 e os peixes foram alimentados duas vezes ao dia. Para a coleta de sêmen, os peixes foram capturados a partir do tanque usando uma rede de mergulho e constrangidos com uma toalha de algodão molhado. Seus olhos estavam cobertos e sua papila urogenital foi limpo e seco com toalha de papel. O sémen foi recolhido em tubos de microcentrífuga que foram imersas em gelo e analisadas imediatamente. A taxa de motilidade média foi $83,33 \%$, a duração de motilidade média foi 5,33 minutos, concentração espermática foi de 1.795 .833 celulas $/ \mathrm{mm}^{3}$ e o vigor 4. A análise morfológica revelou 17,66\% de defeitos de cauda, $20 \%$ de defeitos de peça intermediária e 5,33\% de defeitos de cabeça. O Jundiá da Amazônia (Leiarius marmoratus Gill, 1870) apresenta característica seminais e espermáticas quantitativas e qualitativas que permitem sua utilização em técnicas de reprodução artificial.

PALAVRA-CHAVE: Taxa de motilidade. Duração da motilidade. Morfologia espermática. Bagre Sul Americano.

\section{REFERENCES}

ANDRADE, D. R.; YASUI, G. S. O manejo da reprodução natural e artificial e sua importância na produção de peixes no Brasil. Revista Brasileira de Reprodução Animal, Belo horizonte, v. 27, n. 2, p. 166-172, 2003.

BORGES, A.; SIQUEIRA, D. R.; JURINITZ, D. F.; ZANINI, R.; AMARAL, F.; GRILLO, M. L.; OBERST, E. R.; WASSERMANN, G. F. Biochemical composition of seminal plasma and annual variations in semen characteristics of jundiá Rhamdia quelen (Quoy \& Gaimard, Pimelodidae). Fish Physiology and

Biochemistry, Amsterdam, v. 31, n. 1, p. 45-53,2005. http// 10.1007/s10695-005-4742-8.

CAROLSFELD, J.; GODINHO, H. P.; ZANIBONI FILHO, E.; HARVEY, B. J. Cryopreservation of sperm in Brazilian migratory fish conservation. Fish Physiology and Biochemistry, Amsterdam, v. 63, n. 2, p. 472-489, 2003. http// 10.1046/j.1095-8649.2003.00170.x.

CBRA. Manual para exames andrológicos e avaliação de sêmen animal. 2.ed. Belo Horizonte: Colégio Brasileiro de Reprodução Animal, 1998.49 p.

CRUZ-CASALLAS, P. E.; MEDINA-ROBLES, V. M.; VELASCO-SANTAMARÍA, Y. M. Fish farming of native species in Colombia: current situation and perspectives. Aquaculture Research, Oxford, v. 42, n. 6, p. 823-831, 2011.

FERREIRA, A. A.; NUÑER, A. P. O.; LUZ, R. K.; REYNALTE TATAJE, D.; ESQUIVEL, J. R.; RESTREPO, J. B. Avaliação qualitativa e quantitativa do sêmen de jundiá, Rhamdia quelen. Boletim do Instituto de Pesca, São Paulo, v. 27, n. 1, p. 57-60, 2001.

KAVAMOTO, E. T.; FOGLI DA SILVEIRA, W. Características físicas, químicas e microscópicas do sêmen do bagre Rhamdia hilarii (Valenciennes, 1840) em condições de campo. Boletim do Instituto de Pesca, São Paulo, v. 13, n. 1, p. 95-100, 1986. 
KAVAMOTO, E. T.; BARNABE, V. H.; CAMPOS, B. E. S.; TALMELLI, E. F. A. Anormalidades morfológicas nos espermatozóides do curimbatá, Prochilodus scrofa (STEINDACHNER, 1881) (OSTEICHTHYES, CHARACIFORMES, PROCHILODONTIDAE). Boletim do Instituto de Pesca, São Paulo, v. 25, (único), p. 61-66, 1999.

MATAVELI, M.; MORAES, G. V.; STREIT JUNIOR, D. P.; VARGAS, L. D. M.; SAKAGUTI, E. S.; TONIATO, J. C.; BARBOSA, R. C.; MERLINI, L. Avaliação da qualidade do sêmen de tilápia-do-Nilo (Oreochromis niloticus), linhagem Chitralada, suplementada com diferentes concentrações de vitamina C. Boletim do Instituto de Pesca, São Paulo, v. 33, n. 1, p. 1-7, 2007.

MILIORINI, A. B.; MURGAS, L. D. S.; ROSA, P. V.; OBERLENDER, G.; PEREIRA, G. J. M.; COSTA, D. V. A. Morphological classification proposal for curimba (Prochilodus lineatus) sperm damages after cryopreservation. Aquaculture Research, Oxford, v. 42, n. 2, p. 177-187, 2011. http// 10.1111/j.13652109.2010.02575.x.

MIRA LOPES, T. M.; MEDINA, R. V. M.; CRUZ, C. P. E. Evaluación de tres protocolos hormonales para la inducción de la espermiación en yaque Leiarius marmoratus. Revista MVZ Córdoba, Córdoba, v. 15, n. 2, p. 2070-2077, 2010.

MURGAS, L. D. S.; FELIZARDO, V. O.; FERREIRA, M. R.; ANDRADE, E. S.; VERAS, G. C. Importância da avaliação dos parâmetros reprodutivos em peixes nativos. Revista Brasileira Reprodução Animal, Belo horizonte, v. 35, n. 2, p. 186-191, 2011.

NAVARRO, R. D.; NAVARRO, F. K. S. P. ; FELIZARDO, V. O.; MURGAS, L. D. S. ; PEREIRA, M. M. Cryopreservation of semen of Thailand tilapia (Oreochromis spp.) fed diet with different oil sources. Acta Scientiarum Technology (Impresso), Maringá, v. 36, n. 3, p. 399-404, 2014.

http://dx.doi.org/10.4025/actascitechnol.v36i3.20076.

RAMÍREZ-GIL, H.; AJIACO-MARTÍNEZ, R. E. Aspectos preliminares de la biología pesquera del yaque, Leiarius marmoratus (Gill, 1870) (Pisces: Siluriformes: Pimelodidae) en la parte alta del río Meta Orinoquia Colombiana. Boletim Cientifico do INPA, Manaus, v. 5, p. 75-87, 1997.

SANCHES, E. A.; BOMBARDELLI, R. A.; BAGGIO, D. M.; SYKORA, R. M.; XAVIER, A. Bogotá, M. M.; Características seminais do cascudo-preto (Rhinelepis aspera). Revista Brasileira de Reprodução Animal, Belo Horizonte, v. 35, n. 3, p. 357-362. 2011.

SILVA, J. M. A. ; MURGAS, L. D. S. ; FELIZARDO, V. O. ; PEREIRA, G. J. M. ; NAVARRO, R. D. ; MELLO, R. A. Características seminais e índices reprodutivos de curimba (Prochilodus lineatus) em diferentes períodos reprodutivos. Revista Brasileira de Saúde e Produção Animal (UFBA), Salvador, v. 10, n. 3, p. 668-677, 2009.

SOARES, F. A. C.; STREIT JR., D. P.; EBERT, A. R.; COLDEBELLA, I. J.; OBERST, E. R. Parâmetros qualitativos do sêmen de jundiá (Rhamdia quelen) no inverno e na primavera. Revista Brasileira Ciências Veterinária, Niterói, v. 17, n. 3-4, p. 129-133, 2010.

STREIT JR., D. P.; SIROL, R. N.; RIBEIRO, R. P.; MORAES, G. V.; GALO, J. M.; DIGMYER, M. Parâmetros qualitativos do sêmen de dourado (Salminus maxillosus) em cativeiro. Boletim do Instituto de Pesca, São Paulo, v. 34, n. 3, p. 337-344, 2008a.

STREIT JR., D. P.; SIROL, R. N.; RIBEIRO, R. P.; MORAES, G. V.; VARGAS, L. D. M.; WATANABE, A. L. Qualitative parameters of the piapara semen (Leporinus elongatus Valenciennes, 1850). Brazilian Journal of Biology, São Carlos, v. 68, n. 2, p. 373-377, 2008b. http://dx.doi.org/10.1590/S1519-69842008000200019. 
STREIT JR., D. P.; SIROL, R. N.; RIBEIRO, R. P.; DIGMAYER, M.; GALO, J. M.; MORAES, G. V.; POVH, J. A. Parâmetros seminais de reprodutores de Pseudoplatystoma reticulatum, em cativeiro, pré e pós-indução hormonal. Revista Brasileira de Reprodução Animal, Belo Horizonte, v. 36, n. 3, p. 188-193, 2012.

VIVEIROS, A. T. M.; FESSEHAYE, Y.; TER VELD, M.; SCHULZ, R. W. ;KOMEN, J. Hand-stripping of semen and semen quality after maturational hormone treatments, in African catfish Clarias gariepinus.

Aquaculture, Amsterdam v. 213, n. 1-4, p. 373-86, 2002. http://dx.doi.org/10.1016/S0044-8486(02)00036-4.

VIVEIROS A. T. M.; GODINHO H. P. Sperm quality and cryopreservation of Brazilian freshwater fish species: a review. Fish Physiology and Biochemistry, Amsterdam, v. 35, n. 1, p. 137-150, 2009.

http://10.1007/s10695-008-9240-3. 